UNRAM Law Review is licensed under a Creative Commons Attribution 4.0 International License, which permits unrestricted use, distribution, and reproduction in any medium, provided the original work is properly cited. p-ISSN: 2548-9267 | e-ISSN : 2549-2365, Open Access at : http://unramlawreview.unram.ac.id/index.php/ulr

\begin{tabular}{c|c|c|c|c|}
\hline Volume & Issue & Page & April & p-ISSN: 2548-9267 \\
\hline 3 & 1 & $25-34$ & 2019 & e-ISSN : 2549-2365
\end{tabular}

\title{
The Role of Legal Culture in Corruption Eradication Effort (A Comparative Study of Indonesian and Japanese Corruption Crime Handling)
}

\author{
Laely Wulandari \\ Fakultas Hukum, Universitas Mataram \\ Email : laelywulandari01@gmail.com \\ Lalu Parman \\ Fakultas Hukum, Universitas Mataram \\ Email : parmanmamiq@gmail.com
}

\begin{abstract}
In a comparative study of Eradicating Corruption in Indonesia and Japan appears that law culture plays a significant role. Indonesia has special institution that deals with corruption while Japan does not have it. Nevertheless, cases of corruption in Indonesia are higher than in Japan. This is due to the Indonesian culture of ewuh pakewuh, reluctant, and has two different views in dealing with corruption. On the one hand, Indonesia rejects corruption, but on the other hand, it commits actions that support corruption. Meanwhile, Japan has a strong culture of shame for committing law violations both at the community level and law enforcement officers.
\end{abstract}

Key Words : Corruption; Comparative law; Legal Culture.

\section{INTRODUCTION}

Corruption is still being a good issue to be discussed. Not only the increasing number of perpetrators, but also due to the mode of corruption itself. Without looking at the gender, both man and woman that commit the acts of corruption is called as corruptor. The label of corruption is not solely intended for Civil Servants, Indonesian Army, Police, employees of the State Owned Corporation, central and regional parliaments, officials and judicial members, conglomerates and private business entities but also labeled to all institutions and community members that work along with the public interest, for example lawyers, public accountants and also notaries.

Poverty is not the main factor that triggers corruption. Corruption can occur because there are some opportunities and desires that happen at the same time. Corruption can be started anywhere and anytime. People who wish to win the tender for a project will try to bribe the authorized officer, and many of them will accept it. Financial managers have the opportunity to commit corruption, state officials have the opportunity to do abuse of power, lawyers have the opportunity to take bribes and the bribed judges will accept it, legislative assembly members have the opportunity to accept bribes from employers for the determination of policies, even supreme judges and constitutional court judges as the justice seekers does not rule out the possibility to commit corruption. 
The system for handling corruption cannot be made in the form of criminal sanctions. Criminal sanctions are only the end of handling corruption which aims to provide a deterrent effect. Pope argues that controlling corruption must focus on two elements, which are the opportunity and desire to commit corruption. ${ }^{1}$ Therefore, the opportunity to commit corruption should be minimized by a strong control of power. Indonesia these days is building a system to decrease the chances of corruption. One of the strategies undertaken is by building an Onlinebased system and cutting various licensing procedures. Establishing supervisory bodies with a good working system also helps to minimize corruption.

Indonesia has legislation that regulates corruption that can be seen in the Law Number 31 from Year 1999 concerning Eradication of Corruption Crime. This law has undergone improvements with the Law of the Republic of Indonesia Number 20 from year 2001 concerning amendments to the Law Number 31 from year 1999 concerning Eradication of Corruption Crimes. The threat of imprisonment given in the law constitutes is the highest criminal threat in the criminal law, namely capital punishment. This capital punishment can be given for anyone who violently violates an act that enriches himself or another person or a corporation that can harm the state's finances or the country's economy and requirements if the condition is carries out in certain circumstances. This particular situation can be used as a reason for criminal offenses for perpetrators of corruption, especially if the criminal offense is committed against funds intended for the prevention of danger, national natural disasters, prevention of widespread social unrest, economic and monetary crisis mitigation, and overcoming corruption. ${ }^{2}$

Indonesia also has a state institution that specifically deals with corruption that is known as Corruption Eradication Commission. This commission was formed based on the law Number 30 from year 2002 concerning the Corruption Eradication Commission. Thus, Indonesia has a Prosecutor's Office, Police and the Corruption Eradication Commission who work together to eradicate corruption.

Viewed from these provisions, the Indonesian state has actually done many things to eradicate this criminal act of corruption, both preventive and repressive efforts. However, Indonesians' Corruption Perception Index is quite high. In 2017, Indonesia occupied ranked 96 out of 180 most corrupt countries in the world in the Southeast Asia. Indonesia was stand behind Singapore (6), Brunei Darussalam (32), Malaysia (62), and even Timor Leste (91). This data showed that Indonesia is in a very desperate condition for its corruption.

Japan is one of the country in Asia that places itself as a clean country in terms of corruption. Although it is not the cleanest country in the world, Japan occupy as the second rank country in Asia and the 20th in the world. Practically, Japan is not very clean from corruption because there are still many gaps that are possible for corruption.

However, it is interesting to learn more about why the Japanese corruption perception index is lower than Indonesia. The researcher obtained preliminary data that the maximum imprisonment threatened for the corruptor in Japan are seven years. Compared to Indonesia, there is clearly far too much criminal threat. Indonesia gives death penalty threats to those who commit corruption in certain circumstances.

Japan does not have a separate body to deal with corruption. So, handling corruption is the same as other general crimes. Meanwhile, Indonesia has the Corruption Eradication Commission with many privileges in its efforts to uncover a case of corruption.

The aforementioned things are the background to find out more about the handling of corruption in Japan and Indonesia, as stated in the article entitled "The Role of Legal Culture

\footnotetext{
${ }^{1}$ Jeremy Pope .(2003). Strategi Memberantas Korupsi, Elemen Sistem Integritas Nasional,. Jakarta :Yayasan Obor Indonesia. p. 25

${ }^{2}$ Provisions regarding this matter contained in the article number 2 paragraph (1) and (2) and the explanation of article 2 paragraph (2) of Law Number 31 from year 1999 Jo Law Number 20 from year 2001.
} 
in Corruption Eradication Effort (A Comparative Study of Indonesian and Japanese Corruption Crime Handling)”.

The comparison of criminal law is not merely comparing about topic, but furthermore is to know each other's weaknesses and strengths. At the end, it is expected to lead to improvement and renewal. For this reason, the problem to be discussed in this study is how to compare the role of legal culture in dealing with corruption criminal acts in Indonesia and Japan.

\section{ANALYSIS AND DISCUSSION}

The word corruption comes from Latin language, which is corroptus. Moreover, it was stated that corruption is originated also from the original word corrumpere, an older Latin language. It is from Latin that most European languages, such as English for the word corruption, corrupt, French: corrupratio, and Dutch: corruption (korruptie) comes from. This Dutch is the word that goes down into Indonesian, which is "corruption"'. In Malaysia, it used the word resuah which was taken from Arabic risywah (bribe) which means a gift given by someone to a judge or another people to win a case not in a justified way or to obtain a position. All theologians agree to prohibit risywah related to the termination of the law, because this act includes sin.

Subekti and Tjitrosoedibio stated that corruption is a fraudulent act, a crime that is detrimental to the states' finances. As for Baharauddin Lopa, quoting the opinion of David M. Chalmers describes the term corruption in various fields that concerning the problem of bribery, which is related to manipulation in the economic field, and concerning the field of public interest. This was taken from the statement that "injurious financial manipulations and deliction in the economy are often labeled as corrupt."

According to Alatas, corruption is a subordination of public interests under the interests of personal goals which includes violations of norms, duties, and general welfare, followed by secrecy, betrayal, fraud and extraordinary ignorance of the consequences suffered by society. In short, corruption is an abuse of trust for personal gain. ${ }^{5}$

Pope states that corruption is an abuse of trust for personal gain. But corruption can also be seen as a behavior that does not adhere to the principle of "maintaining distance", which means that in making economic decisions, whether it is done by individuals in the private sector or by public officials, personal or family relations, can eventually lead to corruption. For example, conflicts of interest and nepotism. The principle of maintaining this distance is the foundation for any organization to achieve efficiency. ${ }^{6}$

\section{Comparison of Criminal Law}

Comparison of criminal law is not a new branch of science but a method used to study law. There are various foreign terms regarding comparisons, namely; Comparative law, Comparative Jurisprudence, Droit Compare (French term), Rechtvergelijk (Dutch term), and Rechtvergleichung (Germany term). There are opinions that distinguish comparative law and foreign law, that are:

1. Comparative law: Studying various foreign legal systems with the intention of comparing them

2. Foreign Law Studying foreign laws with the intention of merely knowing the system itself without intending to compares it with other legal systems

\footnotetext{
${ }^{3}$ Andi Hamzah.(2007) Pemberantasan Korupsi Melalui Hukum Pidana Nasional dan Internasional, Jakarta: Rajawali Press, 2007.p. 7.

${ }^{4}$ Pendidikan Anti Korupsi,(2013) Jakarta:Kementrian Pendidikan dan Kebudayaan RI, p. 2.

${ }^{5}$ Ibid., p. 137

${ }^{6}$ Jeremy Pope, Strategi Memberantas Korupsi Elemen Sistem Integritas Nasional, Jakarta, Yayasan Obor Indonesia, 2003, p. 30.
} 
In the Black's Law Dictionary, it is stated that Comparative Jurisprudence is a study of the principles on legal science using a comparison of various legal systems. RudolfD. Schlessinger in his book put forward about comparative laws ${ }^{7}$, which are as follows:

1. Comparative law is an investigation method that aims to obtain deeper knowledge about certain legal materials

2. Comparative law is not a set of rules and principles of law, also not a branch of law

3. Comparative law is a technique or how to work on the actual elements of foreign law in a legal matter.

Departing from this understanding, it is precisely to use the term of "comparison of law" rather than "comparative law" ${ }^{8}$ as stated by Dr. D Guiten-Bourguis as follows:

"Legal comparison is a comparative method which applied in law. Comparison of law is not a science of law, but a method of study, a method for examining something, and a way of working, which is comparison. If the law consists of a set of rules, it is clear that the Comparative Law (vergelihkende recht) does not exist. Methods for comparing legal rules of various legal systems do not result in the formulation of stand-alone rules; there is no legal rule of comparison".

Comparison of law as a method was also stated by Sunaryati Hartono ${ }^{9}$ is "Comparison of law is not a particular legal field such as land law, labor law or procedural law, but is merely a way of investigating a method to discuss a legal issue in any field".

\section{Legal Culture within Society}

Law is a concretization of the cultural values of a society. The concretization of these values can be in the form of ideas or ideals about justice, equality, patterns of behavior, laws, doctrines, customs, decisions of judges and legal institutions (such as courts, police and prosecutors). Therefore, every society always produces culture, and law is always presents in every society and appears with its own peculiarities. That is why Wolfgang Friedman states that law does not have universal force. Every nation develops their own legal habits as they have their own languages. ${ }^{10}$

According to Darmodiharjo and Shidarta, legal culture is actually identical to the notion of legal awareness, which is legal awareness of the law subject as a whole. Hartono asserts that the Dutch legal experts distinguished between legal feeling (rechtgevoel) and legal awareness (rechtbewutzijn). Community assessment that arises spontaneously is a feeling of law, whereas legal awareness is an abstraction regarding the legal feeling of a legal subject. The legal subject can be an individual or a group of individuals (community) and a certain legal entity. ${ }^{11}$

Related to the legal awareness, Soekanto and Taneko found that legal awareness is related to values, which is the abstraction of conception in humans about the harmony between order and serenity desired. The legal awareness indicators are; (1) people's knowledge about legal regulations (legal awareness); (2) people's knowledge about the contents of legal regulations (legal acquanintance); (3) people's attitudes towards legal regulations (legal attitude); and (4) Pattern of legal behavior (legal behavior). Therefore, to know and measure the level of legal awareness of people which also indicates the level of legal culture of the community can be known through these indicators. ${ }^{12}$

\footnotetext{
${ }^{7}$ Barda Nawawi Arief. (2013) Perbandingan Hukum Pidana, Jakarta:Rajawali pers, p. 5

${ }^{8}$ Ibid. p. 6

${ }^{9}$ Soerjono Soekanto, (1988), Disiplin Hukum dan Disiplin Sosial , Jakarta:Rajawali pers. p. 164

${ }^{10}$ Soerjono Soekanto, (1988), Disiplin Hukum dan Disiplin Sosial, Jakarta:Rajawali pers. p. 164

${ }^{11}$ Darji Darmodiharjo dan shidarta, (1996), Penjabaran nilai-nilai Pancasila dalam sistem hukum Indonesia, Jakarta:Raja Grafindo. p. 154-155

${ }^{12}$ Soerjono Soekanto dan Soeleman B. Taneko, (1983), Hukum Adat Indonesia, Jakarta: Rajawali, p. 348
} 


\section{The Comparison of the Legal Culture in Indonesia and Japan in Eradicating Corruption}

In eradicating corruption, Indonesia has a set of law that specifically addresses to corruption, which is Law Number 31 from year 1999 renewed by Law Number 20 from year 2001 concerning Amendments to Law Number 31 from year 1999 concerning Eradication of Corruption Crimes. Moreover, Indonesia has a special institution that handles corruption issues that are regulated by the Law Number 30 from year 2002 concerning the Corruption Eradication Commission.

Meanwhile, Japan does not have a law or a special agency that regulates corruption. Corruption is equated with other criminal acts, so the material rules are mostly in the Japanese Criminal Code and the formal rules are in the Japanese Criminal Procedure Code (Criminal Procedure Code of Japan, the Act Number 131 of July 10th, 1948). Even though it does not have laws and special institutions, Japan has a good track record in efforts to eradicate corruption due to the survey results of several institutions. The Political and Economic Risk Consultancy ${ }^{13}$ also showed that Japan was the third best country in Asia which was seen by investors who had a low level of corruption.

Although Japan is not always better than Indonesia, it is necesssary to know why Japan can reach achievements and it is known as a country that has a high commitment in eradicating corruption. The first thing that researchers note is Japanese legal culture. Friedman argues that legal culture includes opinions, habits, ways of acting and ways of thinking about someone where all of these were related to the law.

People cannot deny the fact that the legal instruments both legislation and institutions that deal with corruption are sufficient, but were not proportional to the level of corruption in Indonesia which is quite high. Hence, the lack of substantive and structural principles in dealing with corruption in Indonesia is not a major factor in the high level of corruption. If it was not a substantive and structural factor, then culture is the thing that needs to be concern. Cultural factors in society are important to analyze because crime occurs within the community itself. Therefore, the study of legal culture is important to answer the existing problems.

In dealing with corruption, Indonesian societies are likened two sides of a coin, which is opposite to each other but actually inseparable. People dislike corruptor as well as various kinds of corrupt behavior. Indirectly, people supports corruption. This can be demonstrated by giving bribes to government officials, giving special treatment to bureaucrats, taking care of various needs that have to do with the government through brokers, cheating on government tender projects, and even bribing judges for a case. Many of the societies also bribe government officials so that they can be accepted to work in an agency.

Adi in his book entitled The Prevention of Corruption in various Perspectives details several law cultural factors that weaken the law enforcement against corruptors, which are:

a. Oftentimes, Indonesian people ignorance the law enforcement process. Corruption is seen as a chronic disease that is difficult to cure and even a system that integrates with the implementation of the state government. It is seen like the government will be destroyed if the law is truly enforced. This behavior pattern is caused by the views of the people who believed that the settlement of corruption criminal acts is not fully carry out consistently (there is always acknowledgment and compromise). Law enforcement is seen only as a formality.

b. The strong culture of reluctant, ewuh pakewuh, people are seen as small people (kawulo alit, wong cilik) who do not have any power when dealing with authority. The public has the feeling of being reluctant to criticize and to report a deviation, especially if the one who

\footnotetext{
${ }^{13}$ www. Academia edu. (Accesed Oktober 5 , 2018 ) tanggal 5 Oktober 2018
} 
commits is a ruling official. This culture propagates into law enforcement systems including institutions and criminal justice systems. The superiors and the subordinates were supported by a culture of kawulo gusti that places superior as the one who always right. If the suoerior doing some deviations, there is no courage to criticize or report. ${ }^{14}$

Japan is different from Indonesia. There is a typical legal culture among Japanese people and officials, which is the "shame culture". They will get embarrassed if they commit a law of violation. Officials will resign if they committing a crime including corruption. Strict control from the communities and the intense reporting from the media for officials who commits corruption can give more deterrent effects rather than the formal law enforcement. Akira Amari is the small example of the shame habit in Japan. He resigned from his position as a Japan Minister of Economy. Amari resigned although he denied accepting bribes from construction companies. ${ }^{15}$

Another example comes from the Japanese Minister of Financial Services, Tadahiro Matsushita. He was found dead in an investigation of a corruption case that occurred in the ministry he led. Later, Japanese Foreign Minister Seiji Maehara resigned from his position after he was proven receiving donations from South Koreans' people who live in Tokyo. The total donation value he received was only 250,000 Yen (around Rp 25 Million). In fact, the money was not used as a pen for his personal use, but as a contribution to his political party or the Japanese Democratic Party (JDP). Moreover, the Tokushima Governor who was charged from bribing by a Japanese conglomerate. In another case detained the mayor of Shomozuma, Ibaraki. These two officials voluntarily resigned immediately from their positions as governors and mayors. ${ }^{16}$

This culture has not yet emerged in Indonesia. Indonesia tends to be the opposite. Some of the last cases, such as the congregation corruption in Malang Regional House of Representative, the phenomenal case of Setya Novanto that provide an example of the less shame culture which has not become the culture owned by the Indonesian people in terms of corruption. Setya Novanto is a chairman of the Indonesian legislative body. He was accused of committing a criminal act of corruption and there were many lies that he did to evade from the case. He did not resign from his position. In fact, committing new acts which dragged his lawyer to the court because the dispute involved a series of lies.

The massive corruption that was done by the Malang Regional House of Representative is a very worrying corruption case. There are 41 out of 45 members of the Malang RHR were suspected as bribery. They were appointed as suspects by the Corruption Eradication Commission in a bribery case of the Malang Regional Government Budget in the fiscal year of 2015. Instead of being embarrassed, there were photos circulating in the mass media that they were posing with the orange vests (CEC prisoners) while laughing together. There are so many State officials in Indonesia who are entangled in corruption cases from all three, legislative, executive and judicial branches. Even the leaders of high legal institutions, both the constitutional court and the Supreme Court were also caught in corruption.

In addition, with the Hand Arrest Operation that held by the Corruption Eradication Commision in 2018, the CEC has succeeded in securing 15 Regional Heads. In 2017, there are seven Regional Heads and four in 2016. Regarding Hand Arrest Operations, it is not directly related to the culture of shame, but they were not embrassed to ask for some money for the continuity of the project. As revealed by the CEC spokesman ${ }^{17}$ that the corruption mode of a 62

${ }^{14}$ Koeno Adi. (2014).Penanggulangan TIndak Pidana Korupsi dalam Berbagai Perspektif. Malang : Setara Perss. p. 61-

${ }^{15}$ www.bbc.com/Indonesia/dunia/2016.[Accsesed Oktober 6, 2018]

${ }^{16}$ Arif Irwanto Lasantu.Pemberantasan Ekonomi Jepang, www.academia.edu/paper

${ }^{17}$ Detik news, 4 Agustus 2018 from : https://m.detik.com [Accesed Augst 4, 2018] 
number of regional heads caught is the bribery related to infrastructure projects or procurement, filling in positions, licensing arrangements and ratification of the budget, ratification of Regional Government Budget regulations, forest conversion and forest area exchange.

There have been many things done by the state to eradicate corruption, but it still does not reduce the level of corruption cases. For this reason, there are a number of things that need to be corrected in handling corruption in Indonesia, where many of the corruption management processes adapt to the Japanese State as a comparison in this study. These things are:

\section{Construct the Community Trust Towards the Judicial System}

Japan does not have a special body that handles corruption. The handling of corruption cases is carried out by the Police and the Attorney General's Office. This can be an indication that the level of public trust in the police and prosecutors in Japan is very high. Businesses report Satisfaction reported that in terms of level of satisfaction with the police, less than one in ten residents perceive most or all corrupt police officers. ${ }^{18}$

Unlike Indonesia, police have a less trust from the public. It was not only shown in everyday problems that even in the consideration of the CEC establishment as stipulated in Law Number 30 from year 2002 concerning the Corruption Eradication Commission, it was stated: "That government agencies that deal with corruption are not functioning effectively and efficiently in combating acts corruption crime".

The government institutions meant are the police and prosecutors. Therefore, if the police, prosecutors and courts in Indonesia were effectively in eradicating corruption, Indonesia does not need to have a special commission that handles corruption. However, in such conditions and many legal officers who also commit corruption, special independent institutions that handle corruption are still needed.

In essence, the handling of corruption will be better if a country have an independent justice system. A judicial system that is impartial and capable of playing an important role in efforts to realize equitable, honest, open and responsible governance. One indicator that corruption is rampant in a country is the existence of a court system that does not work. Therefore legal sovereignty is absolutely necessary.

If the justice system has been running from upstream to downstream, it will indirectly build public trust in the criminal justice system, especially the justice system that handles corruption.Afurther effect is that officials and the privatesectorwill rethink ofdoing corruption, because if they commit corruption they will face the institution that cannot be bribed and independently in carrying out their duties.

The upstream of the handling corruption in Indonesia is a penitentiary. The case of the Sukamiskin Penitentiary which found various types of facilities that can be enjoyed by the corrupt prisoners and the arrested prison's chief for receiving gratuities is a grim picture of the Indonesian criminal justice system. This is one of the causes of people's lack of trust in the Indonesian criminal justice system.

\section{Building a Community of Legal Culture}

As Friedman's stated that legal culture can be interpreted as a pattern of knowledge, attitudes and behavior of a group of people towards a legal system. From these patterns, we can see the level of community integration with the relevant legal system. Easily, this level of integration is characterized by their level of knowledge, acceptance, trust and dependence on the legal system itself.

\footnotetext{
${ }^{18}$ www. Business anti corruption com/country-profiles/Japan.
} 
From this understanding, the actual legal culture of the community can be well awakened if the community places trust to a legal system. It has been described that public trust to the legal system can occur if law enforcement officials can carry out their duties properly.

A good legal culture will produce the best works. Someone uses the law or not, obedient or disobedient to the law is very dependent on the components that exist in the law culture. Although it is stated that law consists of three components, which are structure, substance and law culture, but the most influential component in development is the law culture. This is due to the good as any law is made, at the end the success of the law will be determined by the legal culture of the community. ${ }^{19}$ Without a law culture, the legal system will lose its strength as what Friedman asserts that "Without Legal culture, the legal system is called dead fish lying in a basket, not a living fish swimming in the sea". The description of law culture in the legal structure is likened to a machine that produces something, the legal substance is likened to a product produced by a machine and legal culture is anything or anyone who decides to run a machine and limit the use of machinery.

The factor of legal culture community is important to analyze because crime occurs within the community itself. Therefore, the study of legal culture is important to answer the problem of corruption that always happens in Indonesia.

In a country that has been stricken by corruption, people usually will be pessimistic that corruption can be eradicated. In Indonesia, corruption has been around for decades, discussed in various seminars, forums and mass media and the public also knows about this corruption crime and its consequences. Indonesia also has legal instruments both laws and agencies specifically dealing with corruption. However, corruption still exists in Indonesia nowadays, even those who were involved in corruption were spread evenly from the executive, legislative and judicial branches.

Pessimism and the communities' attitude whom ignorance the law enforcement is a legal culture that does not support the handling corruption properly. This attitude arises because the public considers many cases of handling corruption carries out with full compromise and formality.

Indonesian people are typically obedient and ewuh pakewuh. The community has the feeling of being reluctant to criticize or even to report if there are any legal irregularities done by officials. If there are people reported the corruption case, they will usually get problems and even get accused of defamation.

The shame culture such of Japanese society is not owned by the Indonesian society until today. Japanese people are embarrassed when they are caught violating the law, including corruption. This culture of shame needs to be grown in Indonesian society. Education about law culture can be started from an early age from the smallest community groups which are families, schools and other associations. But more importantly, the State officials must set a good example for their citizens in terms of culture.

Japan is also famous for its character education. This character education also applied in schools. "Seikatsuka" is a term used in Japan for the character education that contains education for everyday life. Students are taught about courtesy in society. The theory of character education is also practiced by teachers and students in the field.

Hidayat ${ }^{20}$ also states that there was a ban on giving and receiving tip in Japan. A simple method applied in Japan as an early learning to prevent corruption. Corruption occurs because

\footnotetext{
${ }^{19}$ Esmi Warasih.(2005),Pranata hukum sebuah telaah sosiologis, Suryandaru Utama : Semarang. p. 95

${ }^{20}$ Bagja Hidayat.Cara Jepang Mencegah Korupsi, Artikel. https// Indonesia .com https;// internasional.kompas.com// www. Academia edu.[ Accesed Oktober 5, 2018 ]
} 
there is a giver and recipient. The culture of giving and receiving tip is a culture that can be the forerunner of corruption.

\section{Restricting Opportunities for Corruption}

Besides being intentional, corruption can also occur because of opportunities. Corruption often occurs when people want a victory over large project tenders or want to win a position in the public sector. This is what needs to be anticipated. Indonesia has a strategy to overcome this. For example tenders carried out online, job auctions and reporting of assets that must be carried out by state officials, both before nominating, during office and after taking office.

Japan also has rules about this. It has been described in the previous discussion that Japan does not have a specific law to eradicate corruption, but Japan has the National Public Service Ethic Act and the National Public Ethic Code. These two public services provide guidelines relating to gifts, hospitality and benefits that can be accepted by public officials, as well as applicable reporting thresholds.

In the meantime, what is emphasized in Japan is the issue of ethics, that is oftenly overlooked in Indonesia. Indonesia often considers that giving gifts for certain purposes is reasonable. There are many cases of corruption in Indonesia that occur gratification and giving with the intention to benefit themselves or their groups.

\section{CONCLUSION}

Legal culture plays an important role in handling corruption. Indonesia has special institutions and legislation in handling corruption, but this is weakened by the culture of ewuh pakewuh, reluctant, hates corruption but doing things that support it, and the culture of obedient which causes the high level of corruption.

Meanwhile, Japan does not have special legislation or institution that deals with corruption, but Japanese legal culture that strongly believes in its law enforcement officers and the shame culture of its strong community caused lower cases corruption in Japan rather than Indonesia.

\section{BIBLIOGRAPHY}

Adi, K. (2014). Penanggulangan Tindak Pidana Korupsi dalam Berbagai Perspektif. Malang : Setara Perss

Alkostar, A. (2008). Korupsi politik di negara modern. Yogyakarta : FH UII Press.

Arief. Barda Nawawi.( 2013) Perbandingan Hukum Pidana. Jakarta : Rajagrafindo Persada

Atmasasmita. Romli. (2009). Perbandingan Hukum Pidana. Bandung,: Mandar Maju

Cruz. Peter de. (2012). Perbandingan Sistem Hukum Common law, Civil Law dan Sosialist Law, Bandung: Nusa Media.

Darmodiharjo Darji dan Shidarta. ( 1996). Penjabaran Nilai-Nilai Pancasila Dalam Sistem Hukum Indonesia, Jakarta: Raja Grafindo

Hamzah. Andi. (2007). Pemberantasan Korupsi Melalui Hukum Pidana Nasional dan Internasional,Jakarta:Rajawali Press

Hamzah. Andi. (2012) Perbandingan Hukum Pidana Beberapa Negara, Jakarta: Sinar Grafika

Mulyana Asep N. (2016) Dimensi Koruptif Kebjiakan (Pejabat) Publik, Pergeseran Paradigma Penegakan Hukum Pasca Undang-Undang Administrasi Pemerintahan. Medan: Madju Medan Cipta

Pendidikan Anti Korupsi (2013). Jakarta: Kementrian Pendidikan dan Kebudayaan RI 
Pope. Jeremy. (2003). Strategi memberantas korupsi, Elemen Sistem Integritas Nasional. Jakarta:Yayasan Obor Indonesia

Renggong Rusan. (2016), Hukum Pidana Khusus, Memahami Delik- Delik Di Luar KUHP. Jakarta: Prenamedia Group

Saebani BeniAhmad. (2016). Perbandingan Sistem Hukum Pidana. Bandung : Pustaka Setia

Soekanto Soerjono dan Soeleman B. Taneko. (1983). Hukum Adat Indonesia, Jakarta:Rajawali

Warasih, Esmi. (2005). Pranata Hukum Sebuah Telaah Sosiologis. Semarang :Suryandaru Utama

\section{Laws and Regulations}

Undang-Undang No. 20 Tahun 2001 Tentang Pemberantasan Tindak Pidana Korupsi. Lembar Negara RI Tahun 2001, No. 134. Jakarta : Sekretariat Negara

\section{Website}

https:// internasional.kompas.com/

www.bbc.com/Indonesia/dunia/2016.

www.Businessanticorruption.com/country-profiles/Japan.

Hidayat Bagja. Cara Jepang Mencegah Korupsi, Artikel. https// Indonesia .com https;// internasional.kompas.com//www. Academia edu.[

Arif Irwanto Lasantu, Pencegahan dan Kontrol Sosial; Suatu Strategi Sukses Pemberantasan Korupsi Di Jepang, accessed https://www.academia.edu/4481250/paper_ pemberantasan_korupsi_jepang_arief_final 